\title{
Associated factors with mammographic changes in women undergoing breast cancer screening
}

\author{
Fatores associados a alterações mamográficas em \\ mulheres submetidas ao rastreamento do câncer de mama
}

\author{
Ricardo Soares de Sant'Ana ${ }^{1}$, Jacó Saraiva de Castro Mattos ${ }^{1}$, Anderson Soares da Silva ${ }^{2}$, \\ Luanes Marques de Mello², Altacílio Aparecido Nunes²
}

\begin{abstract}
Objective: To evaluate association of sociodemographic, anthropometric, and epidemiological factors with result of mammogram in women undergoing breast cancer screening. Methods: This is a cross-sectional study with data obtained through interviews, anthropometric measurements, and mammography of 600 women aged 40 to 69 years at the Preventive Medicine Department of Hospital de Câncer de Barretos, Brazil, in 2014. The results of these examinations in the BI-RADS categories 1 and 2 were grouped and classified in this study as normal mammogram outcome, and those of BI-RADS categories 3 , $4 \mathrm{~A}, 4 \mathrm{~B}, 4 \mathrm{C}$, and 5 were grouped and classified as altered mammogram outcome. The statistical analysis included the Student's $t$-test to compare means, as well as odds ratios (OR), with their corresponding $95 \%$ confidence intervals $(95 \% \mathrm{Cl})$, to verify an association by means of the multivariate analysis. Results: Of 600 women evaluated, $45 \%$ belonged to the age group of $40-49$ years-old and $60.2 \%$ were classified as BI-RADS category 2. The multivariate analysis showed that women with blood hypertension (OR: 2.64; 95\%Cl: 1.07-6.49; $p<0.05$ ) were more likely to present changes in the mammography, while physical activity was associated with lower chances (OR: $0.30 ; 95 \% \mathrm{Cl}$ : $0.11-0.81 ; p<0.05)$. Conclusion: Hypertensive women undergoing screening mammography are more likely to present mammographic changes, whereas women practicing physical activity have lower chances $(70 \%)$ of presenting changes in the breast compared with sedentary individuals.
\end{abstract}

Keywords: Breast neoplasms; Mammography; Obesity; Mass screening

\section{RESUMO}

Objetivo: Avaliar a associação de fatores sociodemográficos, antropométricos e epidemiológicos com o resultado das mamografias de mulheres submetidas ao rastreamento. Métodos: Trata-se de um estudo transversal com dados obtidos por meio de entrevistas, avaliação antropométrica e mamografia de 600 mulheres entre 40 a 69 anos, atendidas no Departamento de Prevenção do Hospital de Câncer de Barretos, em 2014. Os resultados de tais exames nas categorias BI-RADS 1 e 2 foram agrupados e classificados neste estudo como achado mamográfico normal, e aqueles das categorias BI-RADS 3, 4A, 4B, 4C e 5 como achado mamográfico alterado. Na análise estatística, utilizou-se o teste $t$ de Student para comparar as médias, bem como odds ratio $(\mathrm{OR})$, com seus respectivos intervalos de confiança de 95\% (IC95\%), na verificação de associação por análise multivariada. Resultados: Das 600 mulheres avaliadas, $45 \%$ pertenciam à faixa etária dos 40 a 49 anos e 60,2\% foram classificadas na categoria BI-RADS 2. $\mathrm{Na}$ análise multivariada, verificou-se que as mulheres com hipertensão arterial (OR: 2,64; IC95\%: 1,07-6,49; $p<0,05$ ) apresentaram maiores chances de alteração na mamografia, enquanto que atividade física foi associada à menor chance (OR: 0,30; IC95\%: 0,11-0,81; $p<0,05$ ). Conclusão: Mulheres hipertensas submetidas à mamografia de rastreamento tiveram maiores chances de apresentarem alterações mamográficas, ao passo que mulheres praticantes de atividade física apresentaram uma chance menor (70\%) de terem alteração na mama em relação às sedentárias.

Descritores: Neoplasias da mama; Mamografia; Obesidade; Programas de rastreamento

\section{INTRODUCTION}

Breast cancer is a multifactorial disease and its several risk factors related to the disease are well known, and they become worse with changes in life habits. Risk factors include age, genetics, family history, endocrine and reproductive factors, alcohol consumption, fat-

\footnotetext{
${ }^{1}$ Hospital de Câncer de Barretos, Barretos, SP, Brazil.

2 Faculdade de Medicina de Ribeirão Preto, Universidade de São Paulo, Ribeirão Preto, SP, Brazil.

Corresponding author: Altacílio Aparecido Nunes - Avenida Bandeirantes, 3,900 - Vila Monte Alegre - Zip code: 14049-900 - Ribeirão Preto, SP, Brazil - Phone: (55 16) 3602-2884 - E-mail: altacilio@fmrp.usp.br Received on: Apr 8, 2016 - Accepted on: May 15, 2016

Conflict of interest: none.
}

DOI: 10.1590/\$1679-45082016A03708 
rich diet, obesity, sedentarism, exposition to ionizing radiation, pre-malignant injuries of the breast and high density of breast tissue. The factors associated with women's reproductive life and longer exposition to endogen estrogens, such as early menarche, nulliparity, use of hormone replacement therapy for more than five years and late age at first delivery are among most important risk factors for breast cancer. ${ }^{(1,2)}$

Some factors are inevitable, such as age and family history, however, in almost $30 \%$ of cases of breast cancer factors can be avoided by adoption of some habits, e.g. healthy eating, regular exercise, adequate weight, moderate alcohol consumption, and non-smoking. ${ }^{(1)}$ Age remains one of the most important risk factors, and incidence growth rapidly up to 50 years and, after this age range, the increase is more moderately. ${ }^{(2)}$

Mammography is currently considered one of the most reliable techniques to early detection of breast cancer, comprising an ideal method to identify subclinical injuries. Among actions that favor early detection of disease, there are clinical breast exams and screening mammography in routine of integral health care for women. According to the outcome, the exam can be classified in screening mammography that is directed to asymptomatic women, and diagnostic mammography recommended for those with signs and symptoms of breast cancer. ${ }^{(1,2)}$ Although not incorporated in routine of public health service, the annual mammography is ensured as right in Brazilian Public Health Services (SUS - Sistema Único de Saúde) to all women aged 40 years or older according to the Federal Law no 11,664, April 29, 2008, that come into effect in 2009.(3) A study suggests annual mammography before diagnosis of breast cancer as a predictor of higher global survival, ${ }^{(4)}$ and, therefore, the screening results in real benefits to the patient with decrease in mortality for this type of cancer. ${ }^{(5,6)}$

Regular exercise is associated with better prognosis and survival in women with breast cancer, in addition it has a protective role against several types of cancer, because it prevents obesity, which is one of the risk factors for the disease. Studies on exercises and their biologic mechanisms shown them as protective factor for breast cancer and this result have increased considerably in the last years. ${ }^{(7-9)}$ The American College of Sports Medicine recommends for general population, a total of 150 minutes weekly of cardiorespiratory exercises in order to reduce mortality and enhance quality of life..$^{(10)}$ However, recommendations regarding level of physical activity (LPA) to reduce breast cancer risk are little longer, the suggestion is 180 minutes of exercises with moderate intensity weekly to reduce risk approximately in $3 \% .^{(11)}$

\section{OBJECTIVE}

To evaluate association of sociodemographic, anthropometric and epidemiologic factors with results of mammograms of women who underwent breast cancer screening.

\section{METHODS}

This cross-sectional study obtained data from interviews, anthropometric assessments and results of mammograms of women assisted at Department of Prevention of Hospital de Câncer de Barretos (HCB) from July 1, 2014 to November 3, 2014.

The study was approved by the Ethical and Research Committee of the Hospital das Clínicas da Faculdade de Medicina de Ribeirão Preto at Universidade de São Paulo and Ethical Committee of HCB, under protocol number 1.169.686 CAAE: 24514413.1.0000.5440. Participants signed the Consent Form, authorized data collection, and publication of results.

In the HCB women aged 40 years or older underwent screening mammograms. In this sense, considering simple random sample with limited population, based in number of exams conducted in the mentioned service $(18,000$ per year) and prevalence of obesity in Brazil in adult women of $16.9 \%$, estimating a tolerable absolute error of $3 \%$ and significance level of $5 \%$, our total sample was composed by 583 women. However, we evaluated 600 women aged between 40 and 69 years who were previously identified to perform screening mammography.

We excluded pregnant women who had pacemakers and who had positive diagnosis for any other type of cancer and presented some type of physical impairment and cognitive deficit.

Interview was carried out in the same day of the mammography using a structured questionnaire. The assessment of level of physical activity practice was applied based in International Physical Activity Questionnaire that measures level of activity and classifies individuals as inactive, irregular active, active and very active. We classified anthropometrical assessment including height measure, body weight, body mass index (BMI) and waist and hip circumference. After finishing data collection, anthropometric assessments and mammography exam, we initiated the follow-up and analysis of report of the exam in which results of breast density and mammography classification were obtained. Result of this exam was interpreted by radiologists according to standardized system known as Breast Imaging Reporting and Data System Mammography (BI-RADS ${ }^{\circledR}$ ) of the American College of Radiology. ${ }^{(12)}$ 
In our study, categories of BI-RADS were classified as incomplete mammography assessment (BI-RADS 0), in which there was need of additional assessment of image or previous mammograms for comparison and complete assessment (final categories), involving BI-RADS 1-5.

Results of mammograms in categories BI-RADS 1 and 2 were grouped and classified as "normal mammography finding". These referred to exams without mammographic findings or those with benign (however with some change). But results of categories BI-RADS 3, 4A, 4B, 4C and 5 were grouped and classified as "altered mammogram finding", in which entailed benign results (however with need of follow-up exams), findings with low suspicion of malignity, intermediate suspicion of malignancy, moderate and high suspicion of malignancy.

Classification of breast density was based in proportion of tissues that composed breast that was described by Wolfe ${ }^{(13)}$ using four patterns: N1 primarily fat, all breast composed almost with fat; P1 - fibroglandular tissue pattern with prominent ducts occupying up to one-third of the breast volume; P2 fibroglandular tissue pattern with prominent ducts occupying more than one-fourth of breast volume, DY; fibroglandular pattern occupying almost all the breast. Patterns N1 and P1, characterized in this study as fat breast and primarily fat breast were considered low density, whereas P2 and DY were considered as dense and predominantly dense with high risk for development of breast cancer.

\section{Data analysis}

Responses related to sociodemographic, epidemiologic, clinical and anthropometric parameters were analyzed in relation to association among independent variables such as BMI and breast density, and dependents (BIRADS categories, normal mammographic findings and altered mammogram finding). To measure and compare degree of linear correlation between variables of BMI and waist-hip circumference ratio, we applied coefficient of Pearson correlation. The $\chi^{2}$ test was used to analyze data concerning differences among categorical variables.

Comparisons between normal distribution parameters were analyzed by Student's $t$ test for independent or dependent samples, when indicated. Parameters without normal distribution or with unknown distribution were compared using the Mann-Whitney test. To evaluate association among obesity, excessive weight, socioeconomic, epidemiologic, anthropometric variables and health we employed univariated and multivariated analyses, considering altered mammogram finding as dependent variable and applying prevalence ratio and odds ratio (OR) with respective confidence interval of 95\% (CI95\%). The level of significant adopted in all analyses was $5 \%$.

\section{RESULTS}

The age of the 600 women included in the study ranged from 40 to 69 years, mean of 51.7 years $( \pm 7.99)$. Participants' mean weight was $72.2( \pm 14.40) \mathrm{kg}$ and mean height was $1.57( \pm 0.06) \mathrm{m}$. Concerning obesity classified by BMI, the mean was $29.38( \pm 5.62) \mathrm{kg} / \mathrm{m}^{2}$, whereas waist circumference was $93.0( \pm 12.57) \mathrm{cm}$ and hip circumference was $103.7( \pm 9.84) \mathrm{cm}$. The mean of waist-hip circumference ratio was $0.89( \pm 0.08) \mathrm{cm}$. Most of participants were aged between 40 to 49 years $(45.0 \%)$, followed by 50 to 59 years $(34.8 \%)$. The majority of women selected were irregularly activity $(47.5 \%)$ whereas those active or very active represented a total of $34.7 \%$ and $3.6 \%$, respectively. We also verified a predominance of women with primarily dense breasts $(60.7 \%)$.

In relation to BMI (Table 1), a higher percentage of obese women was seen $(40.5 \%)$, and only $21.5 \%$ were within the BMI considered normal. We also observed high percentage of overweight women $(78.9 \%)$, but few participants $(14.7 \%)$ were classified as normal for abdominal obesity and predominant significant enlarged risk were seen in $64.8 \%$ of participants. Concerning, there waist-hip circumference ratio was predominance of high risk and very high risk of $87.7 \%$ in the sample.

Table 1. Distribution of anthropometrical characteristics of participants according to body mass index

\begin{tabular}{lc}
\hline Variables & $\mathbf{n}(\%)$ \\
\hline Classification by BMI & $3(0.5)$ \\
Underweight & $129(21.5)$ \\
Normal & $225(37.5)$ \\
Overweight & $147(24.5)$ \\
Obesity degree I & $72(12.0)$ \\
Obesity degree II & $24(4.0)$ \\
Obesity degree III & \\
Excess weight & $225(37.5)$ \\
Overweight & $243(40.5)$ \\
Obesity & \\
Abdominal obesity & $88(14.7)$ \\
Normal & $123(20.5)$ \\
Enlarged risk & $389(64.8)$ \\
Substantial risk & \\
Waist-hip circumference ratio & $6(1.0)$ \\
Low risk & $68(11.3)$ \\
Moderate risk & $195(32.5)$ \\
High risk & $331(55.2)$ \\
$\quad$ Very high risk & $600(100.0)$ \\
\hline Total &
\end{tabular}


In table 2 we can observe data concerning results of mammograms according to BI-RADS ${ }^{\circledR}$ classification. We also observed that only $7.4 \%$ of exams were classified in BI-RADS 0 category, suggesting an additional evaluation with other complementary exam. Among women who underwent mammography in the period of investigation, $94.8 \%$ had their exams classified as normal in BI-RADS 1 and 2 classification, after reclassification of BI-RADS 0. Other categories of BI-RADS entailed $5.2 \%$ of the sample.

Table 2. Results of mammograms based on BI-RADS classification

\begin{tabular}{lcccc}
\hline $\begin{array}{l}\text { BI-RADS } \\
\text { categories }\end{array}$ & $\begin{array}{c}\text { Right } \\
\text { breast }\end{array}$ & Left breast & Total & $\begin{array}{c}\text { Changes in both } \\
\text { breasts }\end{array}$ \\
\hline 0 & $\mathbf{n}(\%)$ & $\mathbf{n}(\%)$ & $\mathbf{n}(\%)$ & $\mathbf{n}(\%)$ \\
N1 & $33(5.5)$ & $56(9.3)$ & $89(7.4)$ & $0(0.0)$ \\
2 & $206(34.3)$ & $209(34.8)$ & $415(34.6)$ & $0(0.0)$ \\
3 & $362(60.3)$ & $361(60.2)$ & $723(60.2)$ & $0(0.0)$ \\
$4 A$ & $23(3.8)$ & $17(2.8)$ & $40(3.3)$ & $40(64.5)$ \\
$4 B$ & $4(0.7)$ & $9(1.5)$ & $13(1.1)$ & $13(21.0)$ \\
$4 C$ & $1(0.2)$ & $4(0.7)$ & $5(0.4)$ & $5(8.1)$ \\
5 & $3(0.5)$ & $0(0.0)$ & $3(0.3)$ & $3(4.8)$ \\
\hline Total & $1(0.2)$ & $0(0.0)$ & $1(0.1)$ & $1(1.0)$ \\
\hline & $633(100.0)$ & $656(100.0)$ & 1289 & $62(100.0)$ \\
\hline
\end{tabular}

Comparison of women's mean age among those with normal mammographic findings and altered mammogram finding of right breast (Table 3), did not show difference between groups $(\mathrm{p}<0.05)$. However, the comparison of mean women's age with normal mammographic findings and altered mammogram finding of left breast that showed difference between the two groups $(p<0.05)$. In comparison of mean value of BMI in women with normal mammographic findings and altered mammogram finding of right and left breast no significant difference was seen $(p>0.05)$.

Table 3. Comparison of mean age and body mass index in women from the study considering normal and abnormal mammogram findings

\begin{tabular}{lcc}
\hline Mammographic finding & Mean age in years $( \pm \mathbf{S D})$ & p value \\
\hline Normal right breast & $51.76( \pm 8.04)$ & $>0.05$ \\
Altered right breast & $51.75( \pm 7.17)$ & \\
Normal left breast & $51.92( \pm 7.97)$ & $<0.05^{*}$ \\
Altered left breast & $48.70( \pm 7.70)$ & \\
\hline & Mean BMl $( \pm S D)$ & $p$ value \\
\hline Normal right breast & $29.38( \pm 5.55)$ & $>0.05$ \\
Altered right breast & $29.40( \pm 6.81)$ & $>0.05$ \\
Normal left breast & $29.47( \pm 5.71)$ & \\
Altered left breast & $27.69( \pm 3.10)$ & \\
\hline
\end{tabular}

* Student's $t$ test for independent samples

SD: standard deviation; BMI: body mass index
In table 4, we observed that presence of systemic arterial hypertension (SAH) appeared as a predictor of changing in mammography because in multivariate analysis this finding suggested that hypertensive women have 2.64 times more chance (OR: 2.64; 95\% CI: $1.07-6.49 ; p<0.05)$ of presenting changes in the breast compared with non-hypertensive individuals. However, the LPA can indicate that active women had 70\% (OR: 0.30; 95\% CI: 011-0.81) less changes in mammograms compared with little active or inactive women.

Table 4. Multivariate analysis of factors associated with mammograms (normal and abnormal) among selected women, left and right breast

\begin{tabular}{lcc}
\hline Variables & $\mathbf{O R}$ & $\mathbf{9 5 \%} \mathbf{C l}$ \\
\hline RBD & 0.09 & $0.01-1.05$ \\
LBD & 19.74 & $1.82-23.45$ \\
Marital status & 0.54 & $0.19-1.47$ \\
Race & 2.18 & $0.92-5.16$ \\
Age range & 0.65 & $0.28-1.51$ \\
SAH & 2.64 & $1.07-6.49$ \\
BMI & 0.85 & $0.23-3.10$ \\
LPA & 0.30 & $0.11-0.81$ \\
Abdominal obesity & 0.40 & $0.08-1.91$ \\
Waist-hip circumference ratio & 12.73 & $0.76-214.08$ \\
\hline OR: odds ratio; 95\%Cl: 95\% confidence interval; RBD: right breast density; LBD: left breast density; SAH: systemic arterial \\
hypertension; BMI: body mass index; LPA: level of physical activity.
\end{tabular}

\section{DISCUSSION}

Breast cancer is one of the neoplasia that more affects women in Brazil, excluding non-melanoma skin cancer, and it is one of the main causes of death from cancer in developed and under developing countries. Although enhancements in breast cancer screening service had occurred, and advances in development of early diagnosis methods and treatment in developed countries, this disease represents the main cause of death among women affected by cancer in many countries, mainly in less developed ones. ${ }^{(14,15)}$

Population screening program are important and efficient to reduce breast cancer mortality because it might detect potential diseases in early stages. ${ }^{(15)}$ Screening with mammography test is adopted as a public health strategy, and it is considered the best method for early diagnosis of breast cancer. ${ }^{(16)}$ Studies suggest that annual mammography before diagnosis of breast cancer is a predictor of increase in global survival, however, these studies highligth that methods and programs to early detection of breast cancer do not reduce the disease incidence, but they can reduce the disease mortality. ${ }^{(17,18)}$ 
The Haikel et al. ${ }^{(19)}$ study about a screening based program in mammography reported strategies on adherence and better optimization in breast cancer detection using this initiative. For these authors, administrators of public health institutions must be always encouraged to adhere to population level program, which might consequently increase participation of these women.

The analysis of obesity prevalence in our sample revealed that most of women were classified as obese $(40.5 \%)$, and $37.5 \%$ as overweight, i.e., excessive weight was seen in $78.0 \%$ of the sample. A study including 145 women without breast cancer who participated in a screening program in South Brazil found a prevalence of obesity of $39.3 \%$ and excessive weight of $76.5 \%$. The study emphasized these alarming rates and highlighted as a possible explanation for high prevalence of excessive weight other associated factors such as low education level and no exercise. ${ }^{(20)}$ Of note is that some studies report categorical data that excessive body fat represents a risk factor to increase incidence of breast cancer, particularly among women in postmenopausal period. ${ }^{(21,22)}$

Based on this fact, it is necessary to identify how obesity can affect and change organism of these women. Obesity is correlated with a number of changes in the organism and, therefore, can affect prognosis of breast cancer. ${ }^{(23)}$ One of this changes is the increase of circulating estrogen levels: an aromatase enzyme found in adipocytes and responsible for conversion of androstenedione into estrogen. ${ }^{(24)}$ Other studies have demonstrated that most of mediating effect of estrogen represent the association of BMI and breast cancer in such a way that estrogen stimulate the division of epithelial breast cells, therefore increasing the risk for mutation, and for this reason, favoring and inducing breast cancer. In addition, hyperinsulinemia which is closely related with obesity, reduces level of sexual hormones binding globulin, and cause an increase in levels of estradiol and testosterone. ${ }^{(25)}$

In our study, the sample was characterized by LPA such as inactive, irregularly active, active and very active participants. We observed a predominance of women categorized and classified as sedentary (61.7\%, inactive and irregularly active participants). By multivariate analysis, we observed an association of LPA with mammography finding, active women present $70 \%$ lower chance of presenting changes in breast compared with sedentary patients. Based on this fact, physical activity seems to be associated with a protective factor against changes in the breast. According to some international agencies such as World Cancer Research
Fund and American Institute of Cancer Research, the regular practice of exercise at least 30 minutes a day is considered a protective factor for breast cancer in postmenopausal period, in addition to help to maintain the healthy level of some hormones. However, evidences of protective effect of this variable are still limited for women in pre-menopause period.(26) Although results did not show a relationship among obesity with changes and prevalence of changes in the breast, the lifestyle, exercise, and eating habits are considered important factors to prevent and reduce breast cancer risks.

Among findings we highlight the SAH in which found an association with change in breast, suggesting that women with hypertension have 2.6 times more chance of presenting changes in the breast compared with normotensive women. A recent study including women with breast cancer found similar prevalence of comorbidities, and it was higher in SAH with $32.8 \%$, thyroid $22.4 \%$ and hypercoloesterolemia with $12.7 \%$. $^{(27)}$ Another large study on metabolic syndrome and initial stages of breast cancer identified higher risk of general mortality attributed to $\mathrm{SAH}$, however, it was not possible to find the same association for breast cancer. ${ }^{(28)}$

Contribution of several modifiable risk factors for global load of breast cancer, except the reproductive, was calculated by some authors, and they conclude that $21 \%$ of all deaths by breast cancer around the world are attributed to alcohol consumption, overweight, obesity and physical inactivity. This proportion was higher in countries with high income $(27 \%)$, and the most important influencers are overweight and obesity. In countries with mean and low income the proportion of breast cancer attributed to these findings was $18 \%$, and physical inactivity was the most important determinant $(10 \%){ }^{(29)}$ However, policies and national programs must be implemented to increase conscience and reduce exposition to risk factors of cancer, and also guarantee provision of information for individuals and support they would need to adopt healthy life habits. ${ }^{(30)}$

\section{CONCLUSION}

Systemic arterial hypertension variables and level of physical activity had significant association with changed mammographic finding. Results showed that although prevalence of overweight and obesity among women in the sample was above the expected for this population, the body mass index did not show significant difference in association with mammographic findings. In relation to level of physical activity, this finding suggested that women considered active had $70 \%$ lower chance of presenting change in the breast compared with sedentary women. 


\section{REFERENCES}

1. Brasil. Ministério da Saúde. Instituto Nacional de Câncer José Alencar Gomes da Silva. Estimativa 2014: incidência de câncer no Brasil [Internet]. Rio de Janeiro: Instituto Nacional de Câncer (INCA); 2014. [citado 2015 Ago 15]. Disponível em: http://www.saude.sp.gov.br/resources/ses/perfil/gestor/ homepage/outros-destaques/estimativa-de-incidencia-de-cancer-2014/ estimativa cancer 24042014.pdf

2. Brasil. Ministério da Saúde. Instituto Nacional de Câncer José Alencar Gomes da Silva. A mulher e 0 câncer de mama no Brasil [Internet]. Rio de Janeiro: Instituto Nacional de Câncer (INCA); 2014. [citado 2015 Set 21]. Disponível em: http://www1.inca.gov.br/wcm/outubro-rosa/2014/exposicao-mulher-cancer-demama.asp

3. Brasil. Lei $n^{0} .11 .664$, de 29 de abril de 2008. Dispõe sobre a efetivação de ações de saúde que assegurem a prevenção, a detecção, o tratamento e 0 seguimento dos cânceres do colo uterino e de mama, no âmbito do Sistema Único de Saúde - SUS. Diário Oficial da União, Brasília (DF); 2008 Abr 30; Seção 1.

4. Engel JM, Stankowski-Drengler TJ, Stankowski RV, Liang H, Doi SA, Onitilo AA. All-Cause mortality is decreased in women undergoing annual mammography before breast cancer diagnosis. AJR Am J Roentgenol. 2015;204(4):898-902.

5. Tabár L, Vitak B, Chen TH, Yen AM, Cohen A, Tot T, et al. Swedish two-county trial: impact of mammographic screening on breast cancer mortality during 3 decades. Radiology. 2011;260(3):658-63.

6. Kremer ME, Downs-Holmes C, Novak RD, Lyons JA, Silverman P, Pham RM, et al. Neglecting to screen women between the ages of 40 and 49 years with mammography: what is the impact on breast cancer diagnosis? AJR Am J Roentgenol. 2012;198(5):1218-22.

7. Neilson HK, Friedenreich CM, Brockton NT, Millikan RC. Physical activity and postmenopausal breast cancer: proposed biologic mechanisms and areas for future research. Cancer Epidemiol Biomarkers Prev. 2009;18(1):11-27. Review.

8. Winzer BM, Whiteman DC, Reeves MM, Paratz JD. Physical activity and cancer prevention: a systematic review of clinical trials. Cancer Causes Control. 2011;22(6):811-26. Review.

9. Katzke VA, Kaaks R, Kühn T. Lifestyle and cancer risk. Cancer J. 2015;21 (2):104-10. Review.

10. Garber CE, Blissmer B, Deschenes MR, Franklin BA, Lamonte MJ, Lee IM, Nieman DC, Swain DP; American College of Sports Medicine. American College of Sports Medicine position stand. Quantity and quality of exercise for developing and maintaining cardiorespiratory, musculoskeletal, and neuromotor fitness in apparently healthy adults: guidance for prescribing exercise. Med Sci Sports Exerc. 2011;43(7):1334-59.

11. Wu Y, Zhang D, Kang S. Physical activity and risk of breast cancer: a metaanalysis of prospective studies. Breast Cancer Res Treat. 2013;137(3):869-82.

12. American College of Radiology (ACR). Breast Imaging Reporting and Data System Atlas (BI-RADS $\left.{ }^{\circledR}\right)$ [Internet] 2013. [cited 2015 Mar 3]. Available from: http://www.acr.org/Quality-Safety/Resources/BIRADS

13. Wolfe JN. Breast patterns as an index of risk for developing breast cancer. AJR Am J Roentgenol. 1976;126(6):1130-7.

14. Azevedo e Silva G, Bustamante-Teixeira MT, Aquino EM, Tomazelli JG, dosSantos-Silva I. Acesso à detecção precoce do câncer de mama no Sistema Único de Saúde: uma análise a partir dos dados do Sistema de Informações em Saúde. Cad Saude Publica. 2014;30(7):1537-50.
15. Ferlay J, Soerjomataram I, Dikshit R, Eser S, Mathers C, Rebelo M, et al. Cancer incidence and mortality worldwide: sources, methods and major patterns in GLOBOCAN 2012. Int J Cancer. 2015;136(5):E359-86.

16. Torre LA, Bray F, Siegel RL, Ferlay J, Lortet-Tieulent J, Jemal A. Global cancer statistics, 2012. CA Cancer J Clin. 2015;65(2):87-108.

17. Chetlen A, Mack J, Chan T. Breast cancer screening controversies: who, when, why, and how? Clin Imaging. 2016;40(2):279-82.

18. Silva FX, Katz L, Souza AS, Amorim MM. Mammography in asymptomatic women aged 40-49 years. Rev Saude Publica. 2014;48(6):931-9.

19. Haikel RL Jr, Mauad EC, Silva TB, Mattos JS, Chala LF, Longatto-Filho A, et al. Mammography-based screening program: preliminary results from a first 2 -year round in a Brazilian region using mobile and fixed units. BMC Womens Health. 2012;12:32

20. Isoppo de Souza C, Rosa DD, Ettrich B, Cibeira GH, Giacomazzi J, Tusset P, et al. Association of adipokines and adhesion molecules with indicators of obesity in women undergoing mammography screening. Nutr Metab (Lond). 2012;9(1):97.

21. Chan DS, Vieira AR, Aune D, Bandera EV, Greenwood DC, McTiernan A, et al. Body mass index and survival in women with breast cancer-systematic literature review and meta-analysis of 82 follow-up studies. Ann Oncol. 2014; 25(10):1901-14. Review.

22. Hauner D, Hauner H. Metabolic syndrome and breast cancer: is there a link? Breast Care (Basel). 2014;9(4):277-81. Review.

23. Alegre MM, Knowles MH, Robison RA, O'Neill KL. Mechanics behind breast cancer prevention - focus on obesity, exercise and dietary fat. Asian Pac $J$ Cancer Prev. 2013;14(4):2207-12. Review.

24. McTiernan A, Rajan KB, Tworoger SS, Irwin M, Bernstein L, Baumgartner R, et al. Adiposity and sex hormones in postmenopausal breast cancer survivors. Clin Oncol. 2003;21(10):1961-6.

25. Key T, Appleby P, Barnes I, Reeves G; Endogenous Hormones and Breast Cancer Collaborative Group. Endogenous sex hormones and breast cancer in postmenopausal women: reanalysis of nine prospective studies. J Natl Cancer Inst. 2002;94(8):606-16.

26. Wiseman M. The second World Cancer Research Fund/American Institute for Cancer Research expert report. Food, nutrition, physical activity, and the prevention of cancer: a global perspective. Proc Nutr Soc. 2008;67(3):253-6. Review.

27. Fu MR, Axelrod D, Guth AA, Cleland CM, Ryan CE, Weaver KR, et al Comorbidities and quality of life among breast cancer survivors: a prospective study. J Pers Med. 2015;5(3):229-42.

28. Calip GS, Malone KE, Gralow JR, Stergachis A, Hubbard RA, Boudreau DM Metabolic syndrome and outcomes following early-stage breast cancer. Breast Cancer Res Treat. 2014;148(2):363-77.

29. Danaei G, Vander Hoorn S, Lopez AD, Murray CJ, Ezzati M; Comparative Risk Assessment collaborating group (Cancers). Causes of cancer in the world: comparative risk assessment of nine behavioural and environmental risk factors. Lancet. 2005;366(9499):1784-93.

30. Harvie M, Howell A, Evans DG. Can diet and lifestyle prevent breast cancer: what is the evidence? Am Soc Clin Oncol Educ Book. 2015;e66-73. Review. 